\title{
Edelgard E. DuBruck, The Current State of Research on Late-Medieval Drama: 2007-2008. Survey, Bibliography and Reviews
}

\section{Paola Cifarelli}

\section{(2) OpenEdition}

\section{Journals}

\section{Édition électronique}

URL : http://journals.openedition.org/studifrancesi/6564

DOI : 10.4000/studifrancesi.6564

ISSN : 2421-5856

Éditeur

Rosenberg \& Sellier

\section{Édition imprimée}

Date de publication : 1 septembre 2010

Pagination : 344

ISSN : 0039-2944

\section{Référence électronique}

Paola Cifarelli, « Edelgard E. DuBruck, The Current State of Research on Late-Medieval Drama: 2007-2008. Survey, Bibliography and Reviews », Studi Francesi [En ligne], 161 (LIV | II) | 2010, mis en ligne le 30 novembre 2015, consulté le 12 janvier 2021. URL : http://journals.openedition.org/studifrancesi/6564 ; DOI : https://doi.org/10.4000/studifrancesi.6564

Ce document a été généré automatiquement le 12 janvier 2021.

\section{cc) (†)}

Studi Francesi è distribuita con Licenza Creative Commons Attribuzione - Non commerciale - Non opere derivate 4.0 Internazionale. 


\title{
Edelgard E. DuBruck, The Current State of Research on Late-Medieval Drama: 2007-2008. Survey, Bibliography and Reviews
}

\author{
Paola Cifarelli
}

\section{RÉFÉRENCE}

EDELGARD E. DUBRUCK, The Current State of Research on Late-Medieval Drama: 2007-2008. Survey, Bibliography and Reviews, «Fifteenth-Century Studies» 34, 2009, pp. 1-23.

1 Ce travail bibliographique est consacré aux travaux publiés au cours des années 2007-2008 dans le domaine du théâtre de la fin du Moyen Âge et fait suite à d'autres articles parus dans cette revue (cf. par exemple, pour les années 2004-2005, le n. 31 de l'année 2006); il constitue donc un instrument très utile aussi bien pour des études spécifiques, que pour avoir un panorama des tendances de la critique et des recherches menées dans ce champ d'études.

2 Pour ce qui concerne particulièrement la production en français, on y trouvera recensées dans le détail cinq monographies, consacrées surtout au théâtre religieux des Passions et des Mystères, mais aussi à Guillaume Coquillart et à la Farce de Maistre Pathelin. Un certain nombre de contributions contenues dans des volumes collectifs consacrés au drame européen ont pour objet la production en moyen français; on y retrouvera le reflet d'un intérêt assez fort pour les pièces religieuses. 